\title{
The Plankton of the Faröe Channel and Shetlands. Preliminary Notes on some Radiolaria and Copepoda.
}

\author{
By \\ R. Norris Wolfenden, M.D., Cantab., F.Z.S.
}

(With Plates I.-IV. and a Chart.)

IN the year 1899 I commenced a series of tow-nettings round the coast of Shetland, and established four stations-one south of Sumburgh Head (III.), one west of Papa Stour (IV.), one of the northernmost points of Shetland (V.), and one due east of Bressay (VI.). During 1899 my yacht (the Walwin), a cutter of forty tons, made the round of these stations once a month during October, November, and December; and in 1900 during January, February, March, April, May, and June. During July, 1900, a passage was made across to Thorshaven (and back to Scalloway, Shetland), where stations were established, numbered respectively $\mathrm{A} 1, \mathrm{~A} 2, \mathrm{~A} 3, \mathrm{~A} 4, \mathrm{~A} 5, \mathrm{~A} 6, \mathrm{~A} 7, \mathrm{~A} 8, \mathrm{~A} 9$. (See Chart.) During August, 1900, only a short trip to the first two stations in the Faröe Channel was possible. In October, 1900, January, 1901, April, 1901, the stations round Shetland were visited again, and during May, 1901, a further passage was made to Thorshaven and back to Scalloway, visiting the stations previously fixed in the Faröe Channel. This passage was repeated in June, 1901, and again in July, 1901.

At each station round Shetland a surface haul was made with a fine silk net, followed by a vertical haul with an open net; and in February, 1901, I used for the first time a closing net supplied to me by the Plymouth Biological Station, and designed by my friend $\mathrm{Mr}$. W. Garstang. This has subsequently been used on every occasion, both at the Shetland stations and on each trip to the Faröe Islands.

Thermometers were attached to the net, a reversing thermometer of Negretti and Zambra's pattern, supplied with Knudsen's bulb, and a Miller-Casella minimum thermometer; and the temperatures of each haul have been carefully recorded. In addition to these hauls a midwater net of Professor McIntosh's pattern, supplied to me from St. Andrews, was used on every occasion where it was practicable. The procedure adopted has been as follows: At the Shetland stations 


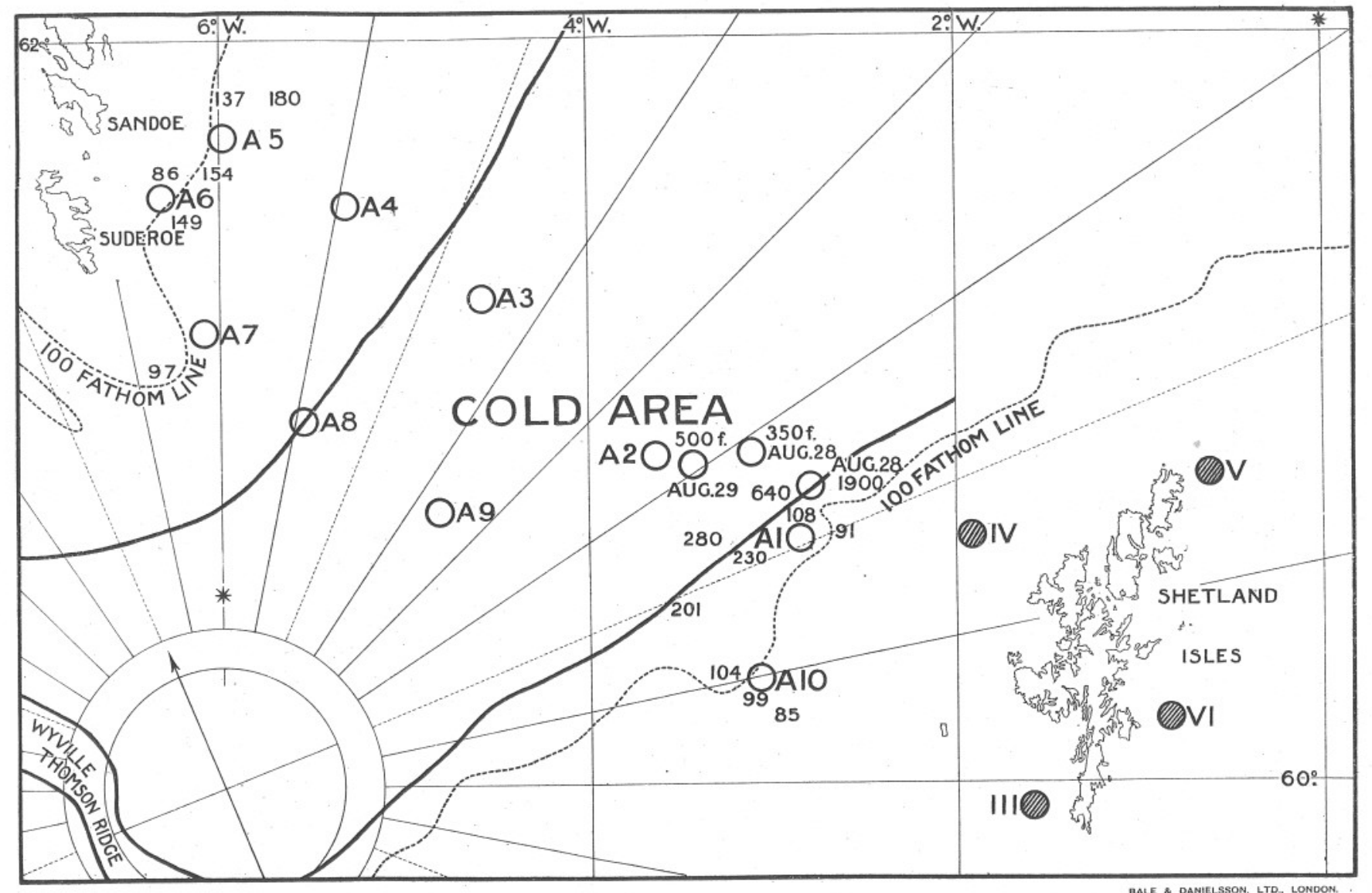

Chati showing Stations at which Tow-nettings were taken in the Faröe Channel and round the Shetland Cosst by DR. Wolfenden. 
a sounding was first taken, then a surface haul, then a vertical haul with open net, and finally a haul from the deepest area with a closing net (Garstang's). Temperature records and water samples * of the area fished were taken, and the mid-water net was towed out behind the vessel while these observations were being made-sometimes (when in deep water) for as much as five hours at a station where much work had to be done. Once over the 100 -fathom line, i.e. in the Faröe Channel, these procedures were repeated at each 100 -fathoms depth down to 500 fathoms, with the omission of the vertical haul with open net, this being considered unnecessary. I have found Garstang's net perform very satisfactorily, and with a fine wire stand quite vertically in the sea. I am aware that objections are urged against a light net of this character in deep water, and Dr. Fowler used in the Faröe Channel a net and wire which, when weighted, exceeded some four times the weight of Garstang's net. I do not intend here to discuss the matter, but will merely remark that my own hauls in deep water agree very closely with those of Dr. Fowler, which were executed with every possible care to ensure accuracy. It is with satisfaction that I note this, and I cannot but think that some of the objections to a light net of Garstang's pattern are more theoretical than practical. Dr. Fowler has very kindly undertaken for me the superintendence of a heavy net of his pattern, which I propose to use in the Faröe Channel; and until I have compared the results of this net with those of the lighter net I defer any remarks as to the vertical distribution of the plankton of this area. An examination of his Copepods taken in his "Research" work (which he has very generously placed at my disposal) shows, however, how closely our results agree.

With the mass of material accumulated during three years' work it has been impossible for me to devote attention to more than two groups, viz. the Radiolaria and the Copepods. My attention was early attracted to the former group on account of the great number and considerable variety which occurred constantly round the Shetland coasts, and because there appears to have been but little work done with respect to this group in British waters. The few notes which Mr. Allen has kindly given me the opportunity of publishing in the Journal of the Marine Biological Association will, I hope, be amplified in a separate publication. The Copepods, the study of which has revealed several new forms, and extension to northern waters of many interesting forms of more or less constant occurrence round the Shetland coasts, will also be more fully dealt with later in a special monograph.

* Mr. H. N. Dickson, of Oxford, has been kind enough to undertake the analysis of my water samples. 
I am greatly indebted to Miss Marion Lees for the beautiful drawings which she has executed, and is still engaged upon, in illustration of my plankton preparations.

\section{RADIOLARIA.}

The COLONY-BUILding Radiolaria are well represented round the Shetland coasts and in the Faröe Channel. Haeckel, in the Challenger Report, described and figured (Plate III.) a Collozoum, to which he gave the name "C. ellipsoides, n. sp." Fowler (Proc. Zool. Soc., December 13th, 1898, p. 1024) speaks of a Collozoum, which he captured in 30 per cent. of epiplankton hauls in the Faröe Channel, of apparently two species, neither of which could be attributed to Collozoum inerme or to Haeckel's Collozoum ellipsoides.

\section{COLLOZOUM.}

A Collozoum which I have captured in several tow-nettings, and on many occasions round the coasts of Shetland, agreed in all particulars with the same organism which I also obtained in considerable quantity in surface tow-nettings in the Faröe Channel. It bears considerable resemblance to Collozoum pelagicum (Brandt), but does not fully agree in important particulars with any of the Collozoums described by Brandt or Haeckel.

The colonies are yellowish in colour, and sufficiently so when in quantity to colour the whole capture a yellowish green. The jelly is often delicate and easily torn. The colonies are for the most part elongated, rarely spherical. Except in what are probably very young colonies, the jelly is of moderately firm consistence. The individuals are at once distinguished by the presence of one or more bright yellow oil drops in the centre of the central capsule. The nests are not closely packed, and the spaces between them are fairly regular.

The zooids are for the most part spherical, and only in cases where division is in progress or about to take place is this form departed from. Then they are lengthened out in the axis, and are frequently "fiddle-shaped." Division appears to be in progress in most of the colonies captured by me in the autumn of 1900 .

The central capsules have a diameter, in the spherical condition, of $\cdot 09-10 \mathrm{~mm}$., and are packed with small round cells. In many colonies the individuals contain only one oil drop, but most have two, and some even three or four, occupying the exact centre of the capsule, and in all cases of a deep yellow colour. Where zooids are undergoing division these oil drops are often small and numerous. A fine membrane appears to surround the central capsule, and round most nests there is a thick 
layer of granular protoplasm, from which arise numerous pseudopodia which ramify through the calymma, and are connected with the extracapsular bodies and spaces. The yellow cells (xanthellae) are numerous -12 to 20 or 30 in an individual-and where the central capsule is dividing many of these appear to be undergoing the same process. They have an average size of $02 \mathrm{~mm}$. Extracapsular bodies are numerous, and contain granular protoplasm, and often what look like small fat drops, but osmic acid fails to stain them.

The description of this Collozoum may be briefly put as follows:Colonies, long and thin, more or less elongated, not segmented. Individuals, $\cdot 09-10 \mathrm{~mm}$. in diameter, round, with thick pseudopodia, central capsule very fine, "assimilation plasma" (Brandt) absent (?); two to four oil drops of bright yellow colour occupying the centre or major portion of the capsule; yellow cells (xanthellae) numerous, 12-30, situated in the "pseudopodia mother-bed" round the capsule.

Distribution: In surface waters round the whole coast of Shetland, and in the Faröe Channel.

The species under discussion-a more detailed description of which is reserved for a future occasion-while possessing some of the characters of $C$. fulvum, much resembles $C$. pelagicum in the possession of yellow oil drops, but differs from the latter in the great number of xanthellae, which in C. pelagicum are only 2-6 per individual. The size of the individual agrees more with $C$. fulvum. We must bear in mind the caution given by Brandt in his painstaking monograph on the colony-building Radiolaria, that it is very difficult to recognise the various Collozoums in their young stages. Besides $C$. inerme, pelagicum, fulvum, hertwigii, Brandt describes eight examples of skeletonless sphærozoida which do not conform with any of the above, some resembling pelagicum, others inerme, others having apparently distinct peculiarities. It may be remarked that Haeckel's description of Coll. pelagicum differs remarkably from that of Brandt,* and the latter, whose careful and minute descriptions, as I have found from experience, appear to be extremely accurate, remarks that under Coll. inerme both Haeckel and Hertwig have confused many different kinds. This northern species of Collozoum, which is certainly not $C$. inerme, appears to more nearly resemble $C$. pelagicum than any other kind.

Quite recently (September, 1901) I have found in Scapa Flow, in Orkney, day after day for a fortnight, quantities of a Collozoum which differs greatly from the organism just described. A detailed study

* Haeckel (Challenger Report) describes C. pelagicum as having small, irregularly shaped central capsules, transparent and without oil globules, often many extracapsular vesicles in the jelly body. Membrane very thin and delicate. Diameter of central capsules, $\cdot 02-08 \mathrm{~mm}$. 
upon living specimens has been possible, since I have captured it in the several stages of development, including the spore-formation stage. The colonies are for the most part globular, never segmented like Coll. inerme, the calymma is delicate and packed with zooids of $\cdot 12-15$ $\mathrm{mm}$. diameter (smallest) to $\cdot 24 \mathrm{~mm}$. (the largest), many in the same colony being quite round, others ovoid or elliptical, but varying as much in shape as size, long, fiddle-shaped (dividing) zooids measuring as much as $: 34 \mathrm{~mm}$. in length.

Similar variation existed in the number and size of the oil drops, the occurrence of one oil globule being quite exceptional, most colonies, except those in the spore stage, containing zooids with a central rosette of eight or nine colourless oil drops, while in long, fiddle-shaped zooids they were more numerous still. The xanthellae were very numerousin many of the young reproductive colonies from 20-30, in individuals of other colonies, which are apparently the same species, being as many as 80-100 per individual. Staining with osmic acid failed to reveal any "assimilation plasma" (Brandt), and the pseudopodia were very fine and the pseudopodium bed surrounding the capsules of moderate thickness. While a detailed description is reserved for a further occasion, it is evident that the organism is not Coll. inerme or Coll. pelagicum, and I have little doubt that it is a new species. What is a further peculiarity is that the calymma is filled with diatoms exactly similar to those described by Brandt (and figured in Plate 2, Fig. 9, of his monograph), ${ }^{*}+$ long bodies $(\cdot 085 \mathrm{~mm}$.) tapering to a fine point at each extremity, thicker in the middle, containing yellow pigment granules and four or five lightly refracting dots which stain darkly with osmic acid. They possess a certain degree of movement in a longitudinal direction, and I have watched them making to-and-fro movements of considerable length through the jelly. Some colonies have a yellowish appearance, to the naked eye, and this appears to depend mostly, if not entirely, upon the number of diatoms present, for the number of green cells does not appear to make any difference, and the oil drops are in all cases quite colourless.

Brandt has already described the occurrence of these diatoms in four colonies of a young kind of Collozoum, which he found in the Mediterranean and which did "not appear to be identical with any known species." The zooids in his Collozoum had a diameter of only 07-09 mm. and contained one colourless oil drop of $\cdot 023-03 \mathrm{~mm}$. diameter with a small pseudopodia layer and no assimilation plasma. This is practically all the description which he was enabled to give of this Collozoum, for which he was unable to assign a specific place.

* Die Koloniebildenden Radiolarien.

+ This does not appear to be an accidental occurrence, but a constant association. 
I think it is possible that the Collozoum ellipsoides ( $n . s p$.) described briefly by Haeckel.* ("central capsules regularly ellipsoidal, very large; length $0 \cdot 3-0.4$, breadth 0.2 ; in every capsule $50-80$ oil globules") may be a stage of the same organism. This Collozoum has been watched by me in the spore-forming stages, and I have studied both the anisospore and isospore conditions. A study of these Collozoums has convinced me how little reliable can be a differential classification of these organisms based on the shape of the zooids, as indicated by Haeckel (p. 24 of the same monograph).

These swarms of Collozoum were observed in Scapa Flow to come to the surface on an exceedingly hot day with a burning sun and quite calm sea. As soon as any ripple of the surface occurred, with a breeze of wind, they disappeared below the surface, and were found 10-12 fathoms deep. It is probable that temperature affects them but little, as I experimentally submitted the living colonies to a temperature of $33^{\circ} \mathrm{F}$. and found that after two hours' treatment they still floated at the surface, and at the other extreme a temperature of $80^{\circ} \mathrm{F}$. did not affect their vitality. Choenicosphcera murrayana has been captured by me, living, in the sea at a temperature of $29^{\circ} \mathrm{F}$. Wind, tidal and other currents have probably more to do with distribution in these cases than temperature.

In assigning any Collozoum to its specific place, no system can be reliable which does not take into full account the various stages in the life-history of the organism. I therefore quote from Brandt's monograph the following data arranged in tabular form and with which I have incorporated the new species (to which I have given the name C. brandtii). These serve for the discrimination of the known European species, or as type forms round which others may be grouped.

\footnotetext{
* Challenger Report, "Radiolaria," p. 26.
} 


\begin{tabular}{|c|c|c|c|c|c|c|c|}
\hline & Colony. & Zooids. & $\begin{array}{l}\text { Central Capsule } \\
\text { Membrane. }\end{array}$ & $\begin{array}{c}\text { Assimilation } \\
\text { Plasma. }\end{array}$ & Nuclei. & Xanthellae. & $\begin{array}{l}\text { Behaviour under chro- } \\
\text { mic acid. }\end{array}$ \\
\hline 1. Coll. inerme & $\begin{array}{l}\text { Sausage-shaped, with } \\
\text { large vacuoles }\end{array}$ & $\begin{array}{l}0.1-0.13 \mathrm{~mm} . ; \text { often } \\
\text { irregular }\end{array}$ & Absent & Occurs & 2 layers & $\begin{array}{l}\text { Numerous ; nearly } \\
\text { all round central } \\
\text { capsule }\end{array}$ & $\begin{array}{l}\text { Jelly dissolved; } \\
\text { zooids fall out }\end{array}$ \\
\hline 2. Coll, fulvum & $\begin{array}{l}\text { Round; one large cen- } \\
\text { tral vacuole }\end{array}$ & $\begin{array}{l}0.09-0.14 \mathrm{~mm} \text {; gener- } \\
\text { ally round }\end{array}$ & Fine & Occurs & 2 layers & Very numerous & $\begin{array}{l}\text { Colony loses its } \\
\text { form }\end{array}$ \\
\hline 3. Coll, pelagicum . & $\begin{array}{l}\text { Thin, sausage-shaped; } \\
\text { often exceedingly } \\
\text { long; never seg- } \\
\text { mented }\end{array}$ & $\begin{array}{l}0.8 \mathrm{~mm} \text {; mostly } \\
\text { round; oil drops } \\
\text { brown-yellow ; } \\
\text { thick pseudopodia }\end{array}$ & Fine & Absent & 1 layer & $\begin{array}{l}\text { Few; } 2-6 \text { pro indi- } \\
\text { vidual; all round } \\
\text { the central cap- } \\
\text { sule }\end{array}$ & $\begin{array}{l}\text { Jelly dissolved; in- } \\
\text { dividuals fall out }\end{array}$ \\
\hline 4. Coll. hertwigii . & Round & $\begin{array}{l}0.12-0.22 \mathrm{~mm} \text {.; mostly } \\
\text { round; often ellips- } \\
\text { oid or kidney - } \\
\text { shaped }\end{array}$ & Thick & Absent & $?$ & $\begin{array}{l}\text { Numerous ; all } \\
\text { round the central } \\
\text { capsule }\end{array}$ & $\begin{array}{l}\text { Colony retains its } \\
\text { form }\end{array}$ \\
\hline $\begin{array}{c}\text { 5. Coll, brandtii } \\
\text { (nov. sp.) }\end{array}$ & $\begin{array}{l}\text { Round or slightly } \\
\text { elongated; never } \\
\text { segmented; num- } \\
\text { erous vacuoles. }\end{array}$ & $\begin{array}{l}\text { '13-24 mm.; ovoid, } \\
\text { ellipsoid, or round; } \\
\text { oil drops } 5-10 \text {, col- } \\
\text { ourless }\end{array}$ & $\begin{array}{l}\text { Absent in young } \\
\text { condition ; ex- } \\
\text { tremely fine in } \\
\text { isospore stage }\end{array}$ & Absent & 1 layer & $\begin{array}{l}\text { Very numerous; } \\
\text { usually } 30 \text {, often } \\
\text { over } 100 \text {; round } \\
\text { the zooid }\end{array}$ & $\begin{array}{l}\text { Jelly partially dis- } \\
\text { solved;zooidsheld } \\
\text { more or less to- } \\
\text { gether by slimy } \\
\text { threads of plasma }\end{array}$ \\
\hline
\end{tabular}

Young Reproductive Stagk, with Intracapsular Bodies.

1. Coll. inerme.

2. Coll. fulvum

3. Coll. pelagicum .

4. Coll. hertwigii .

5. Coll. brandtii (nov, sp.)

Yellow cells fall out in
swarm stage
Yellow cells remain in
swarm stage

Old Reproductive Stage,

\begin{tabular}{|c|c|}
\hline Isospore Stage. & Anisospore Stage. \\
\hline $\begin{array}{l}\text { Crystals } \cdot 008-\cdot 01 \mathrm{~mm} \text {. long inside } \\
\text { nucleus; isospores } 0.012 \mathrm{~mm} \text {. }\end{array}$ & $\begin{array}{l}\text { Small crystals ; fat not dis- } \\
\text { torted }\end{array}$ \\
\hline
\end{tabular}

Crystals form outside, small; Small crystals ; fat distorted isospores $\cdot 009-010 \mathrm{~mm}$.

Crystals outside, small

Crystals small and on outer side of nucleus

NoтE.-It is necessary to comprehend the term "Assimilation Plasma" as used by Brandt. By this is meant a peculiar form of plasma which is in some species contained in the pseudopodia bed round the zooids, and occasionally in the pseudopodia, and which by its behaviour to reagents appears to be chemically different from ordinary plasma. It is chiefly distinguished by its reaction to osmic acid, with which it stains brown or black, while the remaining plasma remains unaffected. It probably has some metabolic function, and appears to be entirely absent in some species. 


\section{Spharozoum (ovodimare (?) Haeckel). Plate I., Fig. 5.}

On one occasion only during two years' work have I captured in the tow-net a Sphærozoum. This was at a position almost due west of Papa Stour, in Shetland, and first on the 100-fathom line,

The colony possessed a clear white and firm calymma, with thin strands of finely granular protoplasm. Individuals were of comparatively large size, the largest averaging $\cdot 12 \mathrm{~mm}$. diameter, circular, greenish yellow in colour, containing numerous small cells, and in the centre one large oil drop. The individuals were surrounded by a fine membrane, and there were numerous xanthellæ from 12-20 round each individual. It bore a striking resemblance to Collozoum except for the presence in the calymma of numerous needles lying between, but not upon, the individuals. They consisted invariably of a straight central rod, and generally of three processes or shanks, arising at an oblique angle from each end of the rod. Some rods possessed four shanks at one end, but the general rule was three. They varied much in size, the largest needles being: rods, $\cdot 002 \mathrm{~mm}$. long; shanks, ${ }^{\circ} 003 \mathrm{~mm}$. long. The latter were invariably longer than the rods. Many were quite plain, but others had short, minute processes or thorns on their edges, never, however, so marked as those figured in Haeckel's monograph as characteristic of Sph. punctatum. In this species also, according to Haeckel, the rod is longer than the shanks.

The presence of scattered needles in the calymma suffices to diagnose this Radiolarian as a Sphærozoum. Four species are described by Haeckel as Atlantic or common forms: (1) Sp. hexactinium (captured in the Faröe Channel), having six or seven curved shanks; (2) Sp. ovodimare (Mediterranean and Atlantic); (3) Sp. punctatum (cosmopolitan in warmer seas); (4) Sp. quadrigeminum (North Atlantic), four shanks at each end of the rod.

All colonies" with tangential "punctatum" needles are placed by Brandt under the designation of $S p$. punctatum, but he remarks that there may be many kinds. While this particular Sphærozoum is obviously not the one described as Sp. hexactinium from the Faröe Channel by Haeckel, it agrees in the fact that the shanks are longer than the needles, and more or less in the size of the central capsule with his Sp. ovodimare, and may be provisionally placed with that.

\section{COLLOSPH ÆRIDA.}

\section{Chenicosphara muRRayana.}

This is the commonest form of colony-building Radiolarian occurring on the coasts of Shetland, and I have found it in most tow-net captures from September to March. It was originally briefly described by 
Haeckel as found in the Faröe Channel and named by him after Sir John Murray.

The colony is a hollow sphere of rather tough jelly of from $3 \cdot 6$ to $4 \mathrm{~mm}$. diameter, and the zooids are dotted over it in little white spots, making it quite easy to identify with the naked eye. The cell nests average -18 mm. diameter. The central capsule, of pale yellow-green colour, occupies the greater part of every shell, and averages $11 \mathrm{~mm}$. diameter. In the centre is one oil globule of $\cdot 05 \mathrm{~mm}$. diameter. Between the central capsule and shell is a thick layer of granulated protoplasm, and outside the shell is another similar layer, from which issue pseudopodia in all directions. Each shell individual appears to lie often in an alveole with a distinct finely granulated boundary. The shells have an average diameter of $18 \mathrm{~mm}$.

In the thick "pseudopodia mother-bed" lie the xanthellae, which also occupy the pores of the shells. They are very numerous. Strands of granular protoplasm radiate from the circumferential layer, throughout the jelly mass. For the most part they are not thick, and extracapsular bodies are few and small.

The shells have a general resemblance to the figure in Haeckel's Challenger Report, and many of them answer to his description:-

"Chcenicosphcera n. gen.-Collosphærida with-simple shells, armed on the outside with radial spines, forming elegant coronals around the larger pores.

"Sub-genus 1. Chonicosphcerula.-A coronal of spines around every pore of the shell" (Challenger Report, vol. xviii. p. 102).

The examination of a large number of specimens shows that the number of spines forming the corona is very variable, frequently six or seven, but often less. In the same shell in which some of the pores may have the typical corona others are found with few spines or none at all.

The pores are of unequal size, some large, others small, distributed irregularly, but ten to twelve in the half-meridian.

The coronal spines are very short and there are no spines between the pores.

It is probable that there is more than one variety of Ch. murrayana. All the kinds captured by me in the Faröe Channel and Shetland waters can only be referred to the sub-genus "Chœnicosphærula" (Haeckel), though it may be remarked that the classification founded on the character of the shell only and the coronals of the pores is necessarily a very artificial one.

The form and disposition of the zooids in the calymma appear to vary with the age of the colony. In some instances individuals are met with having an oval shape side by side with spherical individuals. 
On other occasions what are probably very young individuals appear to be without shell, and bear much resemblance to a Collozoum. The number of the coronal spines round the pores of the shell varies considerably, and it is probable that the Trypanosphcera brachysiphon $n s p$. briefly described by Cleve is really a Chœnicosphæra.

Of the other Collosphærida I have found only shells of Acrosphara spinosa, never a colony. These have been brought up in the tow net vertical hauls, on the west coast of Shetland, on three occasions. Its appearance in this locality can be little more than accidental. The shell is a perfect sphere with many short conical spines, rather broad at the base, and tapering to a point and slightly curved. All the spines are similar. They arise at the base from an upward process of shell at the side of the pore, causing the base to appear as if perforated. The pores are irregular in size, large and small being irregularly distributed. The bars between the pores are three or four times the diameter of the smaller of the latter.

Diameter of the sphere, $\cdot 21$; length of spines, $\cdot 002 \mathrm{~mm}$; width of largest pore, about $\cdot 0012$; widest bars, $\cdot 001 \mathrm{~mm}$.

The shell has much resemblance to Ac. echinoides (Haeckel), but does not fully resemble either that or Ac. spinosa.

\section{THALASSICOLLIDA.}

\section{Thalassicolla nucleata.}

This is taken with great frequency in the surface tow net in the coastal waters of Shetland and in the Faröe Channel, and I have found it in quantities in the mid-water net at a depth of 40 to 50 fathoms.

The organisms are, to the naked eye, little spherical balls of clear jelly with a darkly pigmented centre, often densely black, less often cinnamon-brown or yellow. The colour of the pigment is variable.

The thick jelly calymma is characterised, as Hertwig remarked, by (1) the richness in black pigment, (2) the numerous vacuoles. The latter are small near the central capsule, larger towards the periphery. The pigment is contained in a thick layer of the extracapsular sarcode surrounding the central capsule, and is a dense layer of very small round, black, or brown cells. From this layer it radiates in small quantity through the protoplasmic strands which pass in all directions between the vacuoles. Slight pressure of the cover glass is sufficient to shell out the central capsule from the surrounding pigment layer. It is surrounded by a firm membrane, ${ }^{*}$ which on its inner side is

* The dissection of this membrane from the central capsule is very easily accomplished without previous treatment of the specimen. 
lined with a continuous layer of polygonal areas, and perforated by numerous pores. In the centre of the capsule is a rounded nucleus, which, as Hertwig remarks, is easily shelled out of the capsule by pressure, owing to its thick wall.

The contents of the central capsule are rounded bodies of various constitution, some containing oil drops, some granular protoplasm, others pale and clear, and oil drops of varying size, some few of which are large and of cinnamon colour. Numerous vacuoles occur, large and small.

The nucleus has an investing membrane sufficiently dense to allow of its being readily shelled out of the central capsule on pressure. It is closely packed with small round cell-like bodies, amongst which are some large oval, or ellipsoidal, nucleated bodies. The colour of the nucleus is yellow. Diameter of the calymma, $3-4 \mathrm{~mm}$; of the central capsule, $1.1 \mathrm{~mm}$; of the nucleus, $.05 \mathrm{~mm}$.

\section{Thalassicolla Pelagica (Haeckel, Die Radiolarien, 1862).}

This species is distinguished by the small size of the central capsule in comparison with the calymma, the pellucid appearance of the latter, the small amount of pigment, and pale white or yellowish white colour of the central capsule. The jelly of the calymma is much less firm and consistent than that of $T h$. nucleata, and the pigment is much less distributed in strands through the calymma than in the latter, and is nearly entirely grouped round the central capsule. The membrane surrounding the central capsule is thin, and though marked with very close dots (pores), does not possess the polygonal cell area markings of $T h$. nucleata.

The contents of the central capsule are small, round bodies, packed densely between which are many small oil globules, but the latter are grouped into larger drops chiefly round the outer rim of the central capsule and within the central capsular membrane. Between the intracapsular bodies are many small vacuoles, often containing small oil drops.

The nucleus has a fine and porous investing membrane, and is papillated with irregular-shaped protuberances about as long as the radius, and there are a few long, tube-like or vermiform bodies. The rest of the contents of the nucleus appears to be made up of small rounded bodies, between which are spaces resembling vacuoles. Diameter of the calymma, about $3-4 \mathrm{~mm}$; of the central capsule, $0.4-0.6 \mathrm{~mm}$; of the nucleus, $.02 \mathrm{~mm}$.

The third kind of Thalassicolla possesses a remarkable central capsule, and it has been suggested to me that it should be referred to a new genus, for which the term Thalassiosolen is proposed. 


\section{Thalassiosolen atlanticus (nov. genus et nov. sp.).}

In general appearance the animal resembles $T h$. nucleata, in the possession of a vacuolated calymma and a central capsule surrounded by black or dark brown pigment. This latter is very thick, and extends between the extracapsular vacuoles in thick strands. The calymma and vacuoles are otherwise like $T h$. nucleata. The central capsule shells out quite easily, and its investing membrane (which is readily dissected off with needles) is much thinner than that of Th. nucleata, but, like the latter, is perforated by multitudinous fine pores, apparently more numerous than in Th. nucleata, but showing on its inner surface the same polygonal area markings as Th. mueleata.

A narrow space is observed all round the capsular contents and just within the capsular membrane, in which I have been unable to trace anything but oil globules. The whole of the centre of the capsule is occupied by layers of radially disposed, rounded tubes, closely packed in two (or three?) layers converging towards the centre, where their ends lie over and around the nucleus, without, however, any intimate connection with the latter, and towards the periphery branching into two, or sometimes three, club-shaped, closed ends. Throughout the rest of their course they are usually quite straight, and are rarely branched at their proximal ends. These tubes are yellowish in colour, and appear to contain granules and irregularly shaped bodies, which stain deeply with osmic acid. As they dissolve completely in mineral acids they are not of siliceous nature. They leave behind nothing but oil drops. With prolonged treatment by caustic potash the contour of the tubes is not altered. Stained with picrocarmine, the tubes are seen to be filled with granules deeply stained and with clear spaces between them. Treated with ether, and subsequently stained with picrocarmine, the tube contents are unaltered, except that the granules stain deeper than the rest. Osmic acid stains them dark brown or black. They are not fat, and bear a remarkable resemblance to the "assimilation plasma" of the Collozoums. It is difficult to rupture the tubes, and they always break transversely. The granules are arranged down the sides of the tubes, apparently firmly adherent to the walls, and the lumen of the tubes contains a clear space (? filled with fluid intra vitam).

There do not appear to be any vacuoles in the central capsule, as in other Thalassicollidæ, but oil drops of irregular though often considerable size occur between the tubes.

The nucleus is round, and the investing membrane rather dense, and it does not rupture easily. It is packed with small round bodies, with a few of larger size, but contains no vacuoles. A few 
large cinnamon-coloured oil drops are irregularly distributed in its contents.

Diameter of calymma, $2.6 \mathrm{~mm}$; of central capsule, $1.4 \mathrm{~mm}$; of the nucleus, $\cdot 18 \mathrm{~mm}$.

\section{COELODENDRIDA.}

Celodendrum ramosissimum is not unfrequently found in Shetland waters, and I have captured it on the east as well as on the north and west sides.

The skeletal tubes branch dichotomously, each sub-branch doing the same, and becoming progressively smaller and thinner towards the periphery. These tubes are hollow, and the branches are given off nearly at right angles. The smallest and terminal twigs are each surmounted by eight small recurved teeth and end in a knob. The main branches arising from the galea are closed. At each pole three branches arise from the galea, two being together and one a single one. The central capsule is enclosed in a two-valved shell, with numerous large pores of irregular size, a peculiar hard ridge on the surface, and a curved process at the side. The shell is perforated at the base and sides by small, round, irregular pores.

The phæodium is large. Diameter of the entire animal, $8 \mathrm{~mm}$; length of principal branches, $07 \mathrm{~mm}$.; diameter of shell valves, $\cdot 06 \mathrm{~mm}$.

\section{AULOCANTHIDA.}

\section{Aulacantha scolymantha (Haeckel). Plate I., Fig. 3.}

This is a common Radiolarian round all the coasts of Shetland, where I have taken it in greater abundance than in the open waters of the Faröe Channel. As the spines are almost invariably toothed, whereas in Haeckel's A. laevissima (the only known habitat of which is the Faröe Channel) the spines are smooth, my species cannot be referred to the latter. At the same time it must be remarked that they do not quite agree with $A$. scolymantha as received (in the preserved condition*) from Naples, nor quite with Haeckel's pictures (Monograph, 1862), the differences being in the almost invariably excentric position of the central capsule, the smaller quantity of phæodium, and the character of the radial tubes. These taper at each end, and are thickest in the middle. The proxinal end tapers to a rounded extremity, and the distal to a blunt point. Many tubes are slightly

* In my experience no method of preservation retains the form of the animal in such a normal condition as the well-known 5 per cent. formalin. Specimens may be observed in detail on shore when opportunities fail-as they usually do-at sea, within a few weeks with practical certainty that the organisms have retained their normal condition. Spirit or other preservative certainly distorts to a considerable extent, 
curved distally. They bear from 5-15 minute teeth subalternately placed along the edges of the spines, but only in their distal fifth.

The measurements (from average-sized specimens) are: Diameter of the calymma, $\cdot 73 \mathrm{~mm}$.; of the central capsule, $\cdot 16 \mathrm{~mm}$. length of the radial tubes, $\cdot 75 \mathrm{~mm}$.; greatest thickness, $\cdot 01 \mathrm{~mm}$. The radial tubes number from 28-30, never more; the tangential network which surrounds the jelly consists of fine needles, which form a mesh without branching. Like the radial tubes, they are not dissolved by mineral acids. The central capsule is covered with a tough investing membrane, has an operculum (striated), and a nucleus occupying its centre and about half its size. The phæodium is copious.

\section{Aulographis furcellata, n. $s p$. Plate I., Fig. 1.}

This species was captured at 250 fathoms. The animal, in shape more or less spherical, had a diameter of $1.5 \mathrm{~mm}$. The calymma contains a tangential needle system, the needles being thicker than those of Aulacantha, but while crossing and recrossing one another, nowhere branched or anastomosing. The central capsule lies in an extensive phæodella, of which many of the green cells are of very large size. Radiating through the calymma are about 40 tubes, many of which are slightly curved distally. They are broad towards the proximal end, and taper as a rule but slightly towards the distal end; all appear as if grooved in the outer portion, and while some are very broad, others are of much slighter build. At the extremity of each radial tube are two very short simple branches, bearing neither teeth nor spathillæ. Each is curved and more or less crescent-shaped.

Length of tubes, $\cdot 3 \mathrm{~mm}$.; breadth, $\cdot 09 \mathrm{~mm}$. (in middle).

I am unable to refer this to any of Haeckel's Aulographantha, though it bears all the characters of the genus Aulographis. It certainly does not correspond to either of the three forms, $A$. pistillum, penicillata, pandora, the habitat of which is the North Atlantic.

\section{Aulographis tetrancista (Haeckel), variety.}

Plate I., Figs. 2 and $2 \mathrm{a}$.

In this animal there is a tangential needle system in the calymma of rather thick single rods, resembling the last-mentioned species. The diameter of the whole animal is about $2.3 \mathrm{~mm}$., and there is an extensive phæodella. The tubes are frequently slightly curved, a few considerably bent at the distal end. Thick and broad in the middle, they taper towards each end, but more at the proximal extremity, where they terminate in a rounded end. Towards the distal extremity they appear grooved. Each radial tube carries a 
verticil of four (rarely five) thin and rather long divergent branches, slightly curved. Each terminal branch ends in a cushion carrying four or sometimes five very small teeth.

Length of the tubes, $\cdot 88 \mathrm{~mm}$; breadth in the middle, $.08 \mathrm{~mm}$. The length of the terminal branches varies; some are thick and stout, others longer and thinner, five to ten times as long as broad.

This Radiolarian bears considerable resemblance to Haeckel's $A u l$. tetrancista and hexancista, both of which are Pacific deep-water forms.

My specimen was taken at 400 fathoms in the Faröe Channel, and is probably to be regarded as a North Atlantic variety of Aulographis tetrancista, from which it differs slightly.

\section{Aulodendron Boreale, n. sp. Plate I., Figs. 4, 4a, 4b.}

A Phæodarian was captured at 400 fathoms, which, though very much broken and injured, showed some characters distinct enough to enable it to be placed in Haeckel's genus Aulodendron ("Aulocanthida with a veil of tangential needles, and inter-radial tubes which bear numerous irregularly scattered lateral and terminal branches."-Chall. Rep., p. 1588).

The calymma measured $2.5 \mathrm{~mm}$. across; was covered with a veil of stiff, straight, tangential needles unbranched and not anastomosing, but of considerable thickness, the needles measuring in width $01 \mathrm{~mm}$.

The radial tubes, which were irregularly scattered, were very numerous, straight, of fairly equal thickness throughout their length, tapering only slightly or not at all at the proximal end (Fig. 4a), but at the distal end having a constriction below the verticil, which formed a rounded knob bearing in some four, in a few others six slightly curved branches, widely divergent, about $\cdot 055-060 \mathrm{~mm}$. long, and thin (Fig. 4).

In the outer half of the radial tubes branches were given off at irregular intervals, generally alternate, but often two on one side close together. These branches are short and carry a forked or slightly denticulate knob at the extremity (Fig. $4 \mathrm{~b}$ ), and of about the same length as the branches of the verticil. Generally there were twelve lateral branches, all of about the same length. Often they are again branched, the terminal twigs being very small. The length of the radial tubes was very variable, averaging about $12 \mathrm{~mm}$., and the width was similarly variable, some not being more than half the width of others, but averaging $\cdot 02 \mathrm{~mm}$. The proximal ends of the tubes lie centrally over the phæodella, which is very copious.

The animal, while being undoubtedly an Aulodendron, is difficult 
to place specifically owing to its mutilated condition, but it does not appear to agree with any of the five species described by Haeckel (p. 1589, Chall. Rep.), none of which are North Atlantic forms. It is therefore interesting to note the occurrence of the species in the North Atlantic. The characteristics of the radial tubes are quite peculiar.

\section{CHALLENGERIDA ( $J$. Murray, 1876).}

These singular organisms are not uncommon* round the Shetland waters and in the cold area of the Faröe Channel, and I have taken them both in surface and deep tow-nettings. One species, captured by me off the north coast of Shetland in a surface tow-netting, appears to be new.

\section{Challengeron walwini, $n$. sp. Plate II., Figs. 1, 1a.}

The shell, which is longer than broad, presents the usual "diatomaceous" structure. Its margin has twenty-five spines, of which that at the aboral pole is the largest; on each side of this spine is a very short spine. The other spines round the lower edge are long, though not so long as the apical spine, and progressively and regularly diminish in size towards the peristome. The latter presents two lateral slightly curved and divergent teeth and a dorsal bifid tooth. All are beset with short and sharp spines. There is no pharynx.

Dimensions._Length of the shell, $\cdot 18 \mathrm{~mm}$; of the body, $11 \mathrm{~mm}$.; of the peristome, $07 \mathrm{~mm}$; of the lateral teeth of the peristome, $.03 \mathrm{~mm}$; of the principal aboral spine, $03 \mathrm{~mm}$; breadth of the shell, $09 \mathrm{~mm}$.

This animal would appear to belong to Haeckel's subgenus "Challengerosium" ("margin of the shell dentated or serrated with a continuous series of numerous short radial spines"), all of which, with the exception of one (as to which the depth is not stated), C. johannis (taken in the Faröe Channel, Gulf Stream), are deep-water species, and tropical or Pacific.

It was captured at Station V., February 9th, 1900, at the surface.

It is closely related to C. willemoesii (Haeckel), but differs in having a smaller number of marginal spines (in $C$. willemoesii these are fifty to sixty), and the spinulation of the peristome also differentiates it from this.

* In some hauls, e.g. Station A1, in August, 1900, they were captured in great quantity in the Mesoplankton, chiefly at 350 fathoms. 


\author{
Challengeron balfouri (? var:), J. Murray. \\ Plate II., Figs. 2 and 2a.
}

Shell rather broader than long towards the base, compressed laterally, of the usual diatomaceous structure. At the aboral margin are two short conical teeth-one on the ventral, the other on the dorsal aspect. The peristome is deeply cleft ventrally, and strongly keel-shaped dorsally. It is bifid at the apex, with one tooth rather shorter than the other. The peristome is marked with transverse ridges (not the diatomaceous shell structure), especially in the cleft of the ventral side and along the external surface of the peristome and edge of the teeth. The mouth is wide, and has no pharynx.

Length of the shell, $\cdot 2 \mathrm{~mm}$; breadth, $\cdot 212 \mathrm{~mm}$; length of the peristome, $\cdot 093 \mathrm{~mm}$. ; length of the aboral spines, $\cdot 03 \mathrm{~mm}$. ; width of the mouth, $\cdot 05 \mathrm{~mm}$.

\title{
Challengeron balfouri, variety. Plate II., Figs. 3 and $3 a$.
}

This species resembles the preceding, except in the characters of the peristome, which is stouter and posteriorly produced into a rather prominent elbow, above which the peristome ends in two pointed divergent teeth. The peristome is strongly marked with ridge markings, but not on the elbow, and on the ventral aspect in the groove. It is essentially the same, except in the characters of the peristome, as the last species. It was taken at 350 fathoms along with the last species.

Neither of these two species exactly corresponds with Haeckel's description of C. balfouri (Challenger Report, "Radiolaria," p. 1655), which was a surface species. Both the examples described are probably deep-water varieties of $C$. balfouri.

\section{Challengeria tritonis (Haeckel). Plate II., Fig. 4.}

The shell is longer than broad, ovate seen from the dorso-ventral aspect, marked apparently diatomaceously; but this is not of the usual aspect, but consists of simple rounded pits, many of large size, and the usual hexagonal framework between the pits is absent in this case.

The mouth is comparatively small, and forms a rounded opening, situated rather on the ventral aspect of the shell. There is a long peristome tapering to a blunt point, directed vertically, and having fine markings on the dorsal and ventral sides, unbranched and possessing no teeth.

Length of the body of the shell, $\cdot 2 \mathrm{~mm}$; of the peristome, $\cdot 1 \mathrm{~mm}$.; width of the body of the shell, $\cdot 17 \mathrm{~mm}$; ; width of the mouth, $\cdot 04 \mathrm{~mm}$. 
Challengeria zetlandica (n. sp.), Plate II., Fig. 5.

Shell subspherical and strongly compressed (oval seen sideways) with the usual diatomaceous markings. The peristome is long, and at the base nearly as long as the shell, and ovate, and terminates in one bifid tooth. The whole peristome is strongly directed towards the ventral side. The shell is much longer than Haeckel's Ch. sloggettii, and the aboral line is rounded, not straight, as in Ch. sloggettii. It differs from both $C h$. sloggettii and harstoni in the possession of a single bifid tooth, instead of two parallel teeth.

The shell is also much smaller than any of the Challengerida with which I am acquainted, being only $053 \mathrm{~mm}$. long and the peristome $.03 \mathrm{~mm}$. long. The width of the shell (dorsally) is $\cdot 03 \mathrm{~mm}$.

\section{COPEPODA.*}

The Copepoda of the Faröe Channel have been briefly reported on by I. C. Thompson for Fowler (Research Expn. P.Z.S., 1897). In the same paper a list is given of these, with the areas of their vertical distribution. For the present I withhold any comment on these results, my own work in the Faröe Channel not yet being completed, and will only remark that my own captures with Garstang's closing net in the deeper waters of the Faröe Channel have produced results agreeing in the main with those of Fowler. With work which has accumulated during three years it will be readily understood that it must take a considerable time before a complete survey can be given. I append a first list of Copepoda taken during these expeditions :-

IN THE SHETLAND WATERS.

Calanus finmarchicus.

Calanus parvus.

Calanus hyperboreus.

Pseudocalanus elongatus.

Rhincalanus nasutus.

Eucalanus elongatus.

Eucheta norvegica.
IN THE FARÖE CHANNEL.

Calanus finmarchicus.

Calanus parvus.

Calanus hyperboreus.

Pseudocalanus elongatus.

Rhincalanus nasutus. cornutus.

Eucalanus elongatus.

$E$. attenuatus.

E. crassus.

Euchoeta norvegica.

E. barbata.

E. marina.

Euchirella carinata (nov, sp.).

E. rostrata (?).

* The Copepoda of the Faröe Channel will form the subject of a subsequent monograph. 
IN THE SHETLAND WATERS.

Oithona spinifrons.

Acartia clausii.

, discaudata.

Uncaea mediterranea.

, subtilis.

Metridia lucens.

, longa.

Temora longicornis.

Anomalocera pattersoni.

Centropages typicus.

Candace pectinata.

Pleuromma abdominale.

Etidius armatus.

Ectinosoma atlanticum.

Thaumaleus longispinosus.

Pseudocyclopia giesbrechtii (nov. $s p$.).

Cyclopina gracilis.

Sapphirina (nov. sp.).
IN THE FARÖE CHANNEL.

Oithona spinifions.

Acartia clausii.

Oncera mediterranea.

, subtilis.

Metridia lucens.

, longa.

Temora longicornis.

Anomalocera patter'soni.

Centropages typicus.

Candace pectinata.

Pleuromma abdominale.

$$
\text { , robustum. }
$$$$
\text { , abyssale. }
$$

Heterochceta clausii.

$$
\text { , spinifions. [longicornis) }
$$$$
\text { , zetesios (nov. sp.), (non- }
$$

Tetragoniceps - - (nov. sp.).

Scolecithrix-(nov. sp.).

Agisthus atlanticus (nov. sp.).

Leuckartia flavicornis.

Augaptilus zetesios (nov. sp.).

Atidius armatus.

Ectinosoma atlanticum.

Gaidius boreale (nov. sp.).

I have intentionally not included in this list the Harpacticidæ. It will be noted that several of these Copepods are new species, and I may add that they will form the subject of description subsequently, when the drawings are completed.

There are several additions to the list given in Fowler's paper (loc. cit.), notably Pleuromma robustum, Heterochceta clausii, H. zetesios, Augaptilus, Oncaea, Eucalanus elongatus and crassus, Tetragoniceps, Scolecithrix, Rhincalanus nasutus, and Egisthus.

The limits of distribution of the following "warm-water species" are extended by these observations :-

Euchirella; Eucalanus attenuatus, E. crassus; Euchata barbata; Heterochata clausii, H. spinifrons; Leuckartia flavicornis ; Scolecithrix; Oncae mediterranea and subtilis ; Pleuromma abdominale; Rhincalanus

* Eucalanus crassus, Pleuromma robusta, AEgisthus, Augaptilus I found in Fowler's collection, the two first also occurring in my own tow-nettinge. 
cornutus and nasutus; Thaumaleus; Atidius armatus; Augaptilus; Aigisthus; Gaidius.

Perhaps the most remarkable in this list is Egisthus, of which only four examples are recorded by Giesbrecht, the limits of the species being $3^{\circ} \mathrm{S}$. and $3^{\circ} \mathrm{N}$, $99^{\circ} \mathrm{W}$.

The common Eucalanus of the Faröe Channel is $E$. elongatus. $E$. attenuatus is very uncommon. Eucalanus elongatus is frequently found round the Shetland coast, and on one occasion I took a quantity in Scalloway Deeps.

Rhincalanus nasutus, common in the Faröe Channel, is also often captured off the Shetland coasts. Pleuromma abdominale I have only once captured off the north coast of Shetland, and Pleuromma robustum is quite as common in the Faröe Channel as $P$. abdominale.

Onccea is common in deep water and up to surface hauls in this region. Euchoeta norvegica I have never taken at the surface, though not unfrequently at forty to fifty fathoms' depth, but this being in an open "mid-water net," it may very well have been caught on the way up.

Scolecithrix is not uncommon in the Faröe Channel, but I am unable to refer my specimens to any described species. Curiously I have never succeeded in finding (though I have sought diligently) the Metridia normani which Giesbrecht records from the Faröe Channel. In few tow-nettings is $M$. lucens (and in deep water $M$. longa) absent, and of very common occurrence is a $\delta$ Metridia with the clasping antenna on the left side, but this species is certainly not M. normani. It very greatly resembles $M$. lucens, except for the peculiar position of its clasping antenna (left side).

Leuckartia flavicornis and Thaumaleus have each been captured only once. The occurrence of such forms as AEgisthus, Augaptilus, and Gaidius in these northern waters is very singular. Calanus hyperboreus, which occurs occasionally around the Shetland coast and frequently in the Faröe Channel, is described by Giesbrecht as a distinct species. Thompson, in his report on Fowler's Copepods (loc. cit.), is inclined to regard it as merely a larger variety of C. finmarch.; but I see no reason to doubt the correctness of Giesbrecht's view, that it has specific differences from the latter.

Augaptilus, Euchirella, Gaidius, and Heterochata appear to be deepwater Copepods, and not to approach the coasts. Anomalocera is apparently one of the very few Copepods (not Harpacticidæ) which never descend into deep water, probably never below fifty fathoms. 
Egisthus atlanticus, nov. sp. (One specimen only, which I found in Dr. Fowler's Research Collection.)

Size $1.45 \mathrm{~mm}$. Tail setæ $5 \frac{1}{2}$ times the length of the whole body, and coalescent throughout their course until just at the end. One is a little shorter than the other, and each ends in a peculiar spine, which articulates with the seta, and probably serves to fix the animal in the mud. This animal, unlike any other Copepod, possesses a sixth pair of feet, each a simple process with two hairs. The fifth feet are characteristic, long, and consist of only one segment. The inner terminal fan differs from Giesbrecht's species mucronatus and aculeatus, arising more proximately than in either of these, and not reaching the end of the terminal fan. The other feet have three-jointed outer and inner branches, and the second basipodite is joined to the first in quite characteristic manner (see Giesbrecht's figures, Fauna und Flora Neapel. Pl. 49).

The anterior antennæ consist of six joints; on the upper margin of the second joint is a strong spine proximally bent, and a long peculiar process (sensory?) on the third joint, and a similar one on the end joint. The maxilla and post. foot jaw agree closely with AEg. mucronatus (Giesbrecht). Of the mandibles only the biting end remains.

The body of the animal is more or less torpedo-shaped, and the head narrows in front, and is produced into a long stout spine, curved downwards and forwards. The animal bears some resemblance to AEg. mucronatus, but is little more than half the size, differs in the length and terminations of the tail setæ, the presence of a long sensory process on the last joint of the anterior antenna, the possession of a three-jointed internal and external branch of the second feet (twojointed in mucronatus), the disposition of the fan bristles of the fifth feet, the length of the bristles on the sixth feet (longer than mucronatus), the absence of teeth on the posterior edges of Th. 2,3 , and 4.

\section{ETIDiUs aRmatus.}

The examples captured by me in the Faröe Channel and round the Shetlands fall into two groups, and further study will probably warrant the differentiation of more than one species.

A large number of apparently adult specimens attain a size only of $1.65-1.7 \mathrm{~mm}$., and in these the rostrum is large and strongly chitinised, the anterior antennæ reach quite to, or a little beyond, the end of the furca, and the tenth, eleventh, and twelfth segments are proportionately a little larger than in the second species, and more 
or less coalesced. The pointed angles of the last thoracic segment are also dorsally more prominent and the spurs are shorter than in the other group (in which they reach beyond the end of Ab. 2).

In the second group the animals are much larger, $2 \cdot 0-2.3 \mathrm{~mm}$. long, the rostrum is smaller, the angular point of the last thoracic segment longer, and the antennæ are shorter, reaching only to the end of the first abdominal segment, and the joints 10, 11, 12 are more clearly segmented.

The specimens examined agree more closely with Giesbrecht's description than Brady's (Challenger Report), whose drawings and descriptions contain many inaccuracies. Brady gives the size of Aitidius armatus at $2.1 \mathrm{~mm}$., Giesbrecht $1.55-1.9 \mathrm{~mm}$., and the latter speaks of the variability in length of the points of Th. 5. These differences may be accounted for by the occurrence of two closely allied species, further discussion of which I defer for another occasion.

\section{Gaidius BOREALE, nov. $s p$.}

Half a dozen specimens captured at 300 fathoms at station A2 exhibited the following characters as described by Giesbrecht (Bull. Mus. Comp. Zool. Harvard, 1895): Short, one-pointed rostrum; the last thoracic segment produced into a long and sharp point. The inner branch of the posterior antenna : outer half $:: 5: 8$. The bristles of the inner branch are $8+6$. The head rounded, and without crest. Abdomen of four segments, the genital segment strongly swollen, but quite symmetrical. Of the swimming feet, the first has a two-jointed exopodite and one-jointed endopodite; the second, third, and fourth have three-jointed exopodites, but while the third and fourth feet have three-jointed endopodites, the second foot has an endopodite with only one joint like the first foot. There is an indistinct trace of segmentation into two joints.

The maxilla and mandible resembles Gaetanus. In the posterior foot jaw the second basal, which is longer than the first, is about three times as long as the five-jointed endopodite. The fourth feet have the stiff, broad bristles on the inner margin of the second basal, which slightly resembles the lamellæ of the same foot of Euchirella rostrata, and of which Giesbrecht remarks, "Die Fiedern am proximalen Theile des Innenrandes des 1 Basalgliedes sind am 4 Fusse breiter, und, wie es scheint, steifer als an den vorhergehenden Füssen, worin man einen Uebergang zu den Lamellen und Stacheln finden wird, welche sich bei Euchirella an der gleichen Stelle finden" (loc. cit.).

The size of my animals is $3.55 \mathrm{~mm}$. ( $q$ ), while that of Giesbrecht's is $3.2 \mathrm{~mm}$. The limits of distribution of Giesbrecht's species were 
$35^{\circ} \mathrm{N}$. to $125^{\circ} \mathrm{W}$. My species differs a little from Giesbrecht's, and may be, from the locality of its occurrence, designated boreale. Only a brief description of Gaidius pungens is available (loc. cit.), the only described species.*

\section{Euchirella carinata ơ nov. sp.}

A male taken at A2, 300 fathoms, measured $3.71 \mathrm{~mm}$. long, the forebody six times as long as the abdomen. The last thoracic segments are rounded. The head is produced into a curious rostrum rather like E. galatea $q$, and dorsally there is a strong crest. There is red pigment about the mouth organs and the mandible chewing end is strongly coloured deep orange-red, the foot jaws having their bristles similarly but slightly coloured. The anterior antennæ reach just to the hind end of the thorax and consist of twenty-three joints. The feet have threejointed exopodites except the second, in which they consist of only two joints, the endopodites of the first feet have one, those of the second feet two, and of the third and fourth feet three segments. There is a pair of rudimentary fifth feet, consisting each of an exopodite and endopodite. The right foot is a little the largest, its external branch of only one segment, in which are indistinct traces of three joints; the terminal joint ending in a blunt rounded process. The internal branch is of one stumpy rounded segment only. The left foot has a one-segmented outer branch, with blunt rounded end, and a short (not half the size of the opposite foot) rounded segment, like a small stump. Neither foot has any trace of spines or hairs.

The anal segment is very short and tucked into the fourth abdominal segment as in other Euchirellas.

The external branch of the posterior antenna is over three times as long as the inner branch, which carries $6+5$ bristles at the end.

There are no spines or bristles on the first basal of the fourth foot.

The twentieth and twenty-first joints of the anterior antennæ are not coalesced, but the antennæ strongly resemble those of Euchirella. 8 and 9 and 24 and 25 are joined.

This Copepod agrees with Euchirella in the possession of twenty-three jointed anterior antennæ, the shape and number of segments of the abdomen, the segments of the branches of the feet, and the posterior antennæ. The maxillæ and foot jaws are well developed, the former very similar to the maxilla of the $q E$. messinensis, the second basal joint of the posterior foot jaw is not quite twice as long as the well-

* The nearest related genus is Gaetanus (Giesbrecht), but this Copepod is removed from it by the absence of any median spine on the head. The indistinct traces of segmentation of the first and second feet cause it to approach the genus Gaetanus, while the lamellæ of the fourth feet (basal joint) again differentiate it. On the whole, it approaches more nearly to Gaidius than Gaetanus. 
developed five-jointed endopodite; in the anterior foot jaw the lobes are large, compressed, and the endopodite articulates behind, as in Etidius. The hooked bristle on the fourth lobe is very strong and longer than that in the fifth lobe. This organ greatly resembles $E$. rostrata. The animal resembles no known o Euchirella (E. amcena, E. messinensis, E. pulchra), but though comparatively large, it may be an undeveloped $\delta$. It will be figured and described subsequently.

\section{Euchirella ? Rostrata (? var.) 9 .}

Size $3.8 \mathrm{~mm}$. There is no crest, but a one-pointed rostrum. The abdomen and genital segment are quite symmetrical. The anterior antennæ have twenty-three joints. The internal branch of the posterior antennæ is as $5: 8$, and the end of the endopodite carries $6+5$ bristles. The fourth feet have peculiar spines on the inner margin of the first basal joint, four in number, one of which is large (the proximal), the others progressively smaller and further proximally from the stout inner hair than in E. rostrata, which it most resembles. The maxilla is very similar to $E$. rostrata, and the mandible is similarly like, except that the inner tooth of the chewing end is much longer and sharper. The absence of a crest and the symmetrical genital segment and spines of the basal joint of the fourth feet differentiate it from $E$. pulchra o.

The larger size and number of bristles on the endopodite of the posterior antennæ and smaller number of spines (or triangular lamellæ) on the fourth basal differentiate it from E. rostrata, of which, however, it may be a variety. It will be described and figured subsequently.

Two perfect specimens were captured at 300 fathoms.

\section{HETEROCH}

Length $3.5 \mathrm{~mm}$. This Copepod, found in Fowler's Research Collection, was in very good state of preservation, except that the end segments of the anterior antennæ and tail setæ were damaged. The portion of the anterior antennæ left (nineteen joints) reached a length of $4 \mathrm{~mm}$., so that it was much longer than the whole length of the animal. The geniculation occurs between the eighteenth and nineteenth joints. The basal joint of the posterior foot jaw has bristles, but no long spine, and the last two lobes of the anterior foot jaw carry plain hooks not beset with comb teeth. The fifth lobe is very much longer than any of the others, and its hooked bristle is stouter than that of lobe 4, and is quite without teeth or hairs, while that of lobe 4 is beset with fine short bristles. The mandibles, unlike H. longicornis (of which it might possibly be the ${ }^{\circ}$, but 
the ${ }^{7}$ of this species is unknown), are not alike, the chewing end of one carrying two trifid, one single pointed, and one long, stout, pointed outer tooth (four in all), whereas the chewing end of the opposite mandible carries only two slenderer, long, pointed teeth. The exopodite of the mandible carries four extraordinarily long and densely feathered bristles, the endopodite is well developed. The last joint of the outer branch of the fourth feet is of similar form to that of the third foot. The fifth feet are unlike those of any known Heterochæta, the second basal of the right foot being produced into a long comb-like process with stiff, short bristles on the inner margin, the first segment of the exopodite is small, the second very large and very broad with the internal margin armed with two protuberances, one having a series of short teeth, the other and distal one armed with a few stiff bristles. The second basal of the left foot has a rounded and projecting distal inner margin armed with stiff bristles. The bristles of the posterior antenna are of great length and densely feathered.

In size, length of anterior antennæ, characters of the basal joint of the posterior foot jaw, and of the anterior foot jaw, and normal shape of the third segment of the exopodite of the fourth foot this Copepod resembles H. longicornis (Giesb.). The $\delta$ of this species is, however, unknown, and the example under notice may possibly be this, or a new species. Provisionally I name it zetesios.

\section{Pleuromma robustum, Dahl.}

Many examples of this Copepod have been captured in my Faröe tow-nettings, and I found several examples of it in Fowler's Research Collection. The of averages $4 \mathrm{~mm}$. length, the of $355-3.7 \mathrm{~mm}$. The pigment spot is always on the right side of the body, and the clasping antenna on the left. The teeth of the anterior antennæ are small, and both the second feet have excavations and teeth on the first segment of the internal branch. The abdomen is quite symmetrical. Dahl remarks of this species that though found in tropical areas of the ocean singly and in deep water, it has a wide distribution, and in northern regions comes nearer to the surface, having been once taken in the vertical net from 100 metres to the surface. I have taken it several times in the closing net at 100 and 150 fathoms.

\section{Thaumaleus longispinosus $\sigma^{7}$.}

Only the $\delta$ of $T h$. longispinosus and Th. thompsonii are known, and the furca of the former has four bristles, while that of the latter species has only three. If the tail bristles are to be regarded as of constant diagnostic value, this specimen approaches more nearly to $T h$. longi- 
spinosus in the possession of four furcal bristles. The whole length of my specimen is $1.19 \mathrm{~mm}$., and the relative length of abdomen to cephalothorax is as 1 to 4 , somewhat different from Giesbrecht's measurements, making the body in the Shetland specimen larger in proportion. Thaumaleus longispinosus was taken by Bourne at Plymouth in 1890, and Th. claparedii by Scott in 1889 in the Firth of Forth, and by Thompson in 1889 in Liverpool Bay; but so far as I am aware no Thaumaleus has been captured so far north as Shetland before.

\section{Augaptilus zetesios, n. $s p$. Plate III.}

Total length $4.71 \mathrm{~mm}$., of moderate transparency. Head separate from thorax, with weak rostrum situated on a papilla. Abdomen three segments, the genital longer than both the others together. Furcal segment four times as long as broad. Anterior antennæ of twentyfive segments, and reaching considerably beyond the end of the furca. The outer branch of the posterior antennæ is a little the longest. The hairs of the outer branch are very long and feathered; those of the other branch shorter and naked. Mandibles have a long and thin chewing end with two large and one very small teeth. Maxillæ have all the outer and inner lobes except the first (of each) suppressed. The bristles are of very great length. The bristles of the second basal and endopodite of the anterior foot jaws carry two series of the peculiar "hutpiltzformigen Anhange" characteristic of Augaptilus (see Fig. 12). In the posterior foot jaws the bristles of the endopodite are similarly armed. The swimming feet have each three segmented inner and outer branches. The outer spine on the first segment of the exopodite of the first foot is very long and closely haired, and the distal segment carries two long tapering naked bristles. In the second and third pairs the long bristle on the second basal (which is present in the fourth feet) is absent. The third segments of the exopodites of the second, third, fourth, and fifth feet have a very convex outer margin, and the spines are very rudimentary. The bristles at the end (especially in the third and fourth feet) are stiff and curved inwards, with long hairs on the inner aspect, and short stiff hairs on the outer. The fifth feet have a rather longer (proportionally) endopodite, and the last joint of the exopodite is shorter than in the second to fourth pairs, while the distal segment of the inner branch is comparatively longer than in the other feet. The second segment of the outer branch carries a long, stout (at the base), and tapering spine nearly as long as the joint and armed on the inner side with stout teeth from the base to the distal end, and many short teeth on the surface and a few stout teeth on the outer proximal margin. This Copepod bears some resemblance to Aug. longi- 
caudatus, Giesb., but is considerably larger. The genital segment is longer than both succeeding segments; the anal segment is half as long again as the middle segment of the abdomen. The bristles of the mandible and anterior foot jaws, and the proportions of the joints of the posterior foot jaws, also differ. The fifth foot differs in relative proportions, and the spine on the second joint of the exopodite is quite peculiar. It differs from Aug. megalurus, especially in the large spine of the fifth foot and the size of the middle segment of the abdomen.

Two specimens were found in Dr. Fowler's collection, one from a bottle marked 19 d.e. Epiplankton, and one from Mesoplankton 20 (stations referred to in his paper in the Proc. Zool. Soc., loc. cit.).

\section{Pseudocyclopia Giesbrechtil, nov. $s p$. Plate IV.}

Length of the whole animal, $.72 \mathrm{~mm}$. (cephalothorax, $575 \mathrm{~mm}$.). Body robust, with a short pointed rostrum, and of four segments. Abdomen slender, of four segments, the first equal in length to the third and fourth. Furcal segment about as long as broad-of the four tail setæ, the two middle of each side are stout, not jointed, and crossringed in their whole length, and feathered throughout; the four shorter hairs are cross-ringed only to the joint. The anterior antenna do not reach to the end of the cephalothorax, and contain seventeen joints, the first joint about equal in length to the succeeding thirteen joints. The posterior antennce have only one branch (internal) composed of four joints. The mandibles are large, with broad chewing end and two-branched palp. The maxillae and anterior foot jaus present nothing unusual, except that the exopodite of the former is suppressed. The posterior foot jaws consist of two basal joints and a five-jointed endopodite. The two basal joints are about equal in length. The endopodite is shorter than the second basal joint.

The Swimming Feet.-The first pair is short, and has three jointed exopodites and one jointed endopodites; the second pair has three jointed exopodites and two jointed endopodites; the third pair has three jointed outer and inner branches. The internal branch of the right foot is longer than that of the left side, the second segment being longer than that of the other internal branch. The distal joint of the outer branch of the left foot is much longer and broader than that of the foot of the other side, has two stout spines on the outer margin, and a long apical spine twice the length of that of the opposite foot, the terminal joint in which carries only one outer marginal spine and a very short apical spine. The long, stout, naked spine arising from the inner distal margin of the first basal joint is in each foot as long as the internal branch. This foot is very remarkable, and may be an ab- 
normality. The fifth feet are very peculiar, consisting each of one branch only, each of the two basal joints and a terminal joint forming three finger-like projections. The second and in greater degree the third and fourth feet have their segments ornamented on the surface with rows of fine spines, and the joints of the endopodites of the third pair are fringed with spines.

The absence of a secondary branch of the posterior antennæ in this species is remarkable. In other particulars, size and spinulation of the feet segments, number of antennæ, joints, etc., it differs from any known species of Pseudocyclopia. I have named it after Dr. Giesbrecht, to whom I showed these drawings when recently I visited Naples. It was captured in the surface tow-net off the island of Bressay, Shetland, in March, 1900.

\section{EXPLANATION OF PLATES I.-IV.,}

Illustrating Dr. R. N. Wolfenden's Paper on "The Plankton of the Faröe Channel and Shetlands."

\section{Plate I.}

1. Aulographis furcellata (nov. sp.), a needle.

2 and $2 a$. Aulographis tetrancista (?) (variety).

2. A short-branched verticil.

$2 a$. A verticil with long branches.

3. A needle of Aulacantha scolymantha.

4, 4a, 4b. Aulodendron boreale (nov. sp.).

5. Needles of Sphcerozoum (ovodimare?).

Plate II.

Challengerida.

1. Challengeron walwini (nov. sp.).

1a. The peristome in different aspect.

2. Challengeron balfouri (?) (variety).

$2 a$. The peristome (enlarged).

3. Challengeron balfouri (?) (variety).

$3 a$. The peristome seen dorsally.

4. Challengeria tritonis.

5. Challengeria zetlandica (nov. sp.).

$5 a$. Viewed ventrally. 


\section{Plate III.}

Augaptilus zetesios (nov. sp.).

1. Whole animal, dorsal ( 2 inch obj. $\times 5$ oc.).

2. Fifth feet ( $\frac{1}{2}$ inch obj. $\times 5$ oc.).

3. Spine on second segment of exopodite of fifth feet ( $\frac{1}{4}$ inch obj. $\times 5$ oc.).

4. Fourth foot $\left(\frac{1}{2}\right.$ inch obj. $\times 5$ oc. $)$.

5. First foot ( $\frac{1}{2}$ inch obj. $\times 5$ oc. $)$.

6. Second and third segments of exopodite of first foot ( $\frac{1}{4}$ inch obj. $\times 5$ oc.).

7. Mandible ( $\frac{1}{2}$ inch obj. $\times 5$ oc.).

8. Maxilla ( $\frac{1}{2}$ inch obj. $\times 5$ oc. $)$.

9. Posterior antenna ( 1 inch obj. $\times 5$ oc.).

10. Anterior foot jaw ( $\frac{1}{2}$ inch obj. $\times 5$ oc.).

11. Posterior foot jaw ( $\frac{1}{2}$ inch obj. $\times 5$ oc.).

12. Processes on bristles of posterior foot jaw ( $\frac{1}{6}$ inch obj: $\times 5$ oc.).

13. Anterior antenna ( 1 inch obj. $\times 5$ oc.).

\section{Plate IV.}

Pseudocyclopia Giesbrechtii (nov. sp.).

1. Whole animal in profile ( $\frac{1}{2}$ inch obj. $\times 3$ oc. $)$.

2. Abdomen, dorsal view ( $\frac{1}{4}$ inch obj. $\times 5$ oc.).

3. First foot, dorsal view $\left(\frac{1}{4}\right.$ inch $\times 5$ oc. $)$.

4. Third feet, ventral view $\left(\frac{1}{4}\right.$ inch $\times 5$ oc.).

5. Fourth foot $\left(\frac{1}{4}\right.$ inch $\times 5$ oc. $)$

6. Second foot, dorsal view ( $\frac{1}{4}$ inch $\times 5$ oc.).

7. Fifth feet, dorsal ( $\frac{1}{4}$ inch $\times 5$ oc.).

8. Anterior antenna.

9. Posterior antenna.

10. Mandible.

11. Maxilla.

(All $\frac{1}{4}$ inch obj. $\times 5$ oc.).

12. Anterior foot jaw.

13. Posterior foot jaw. 


\section{Plate I.}
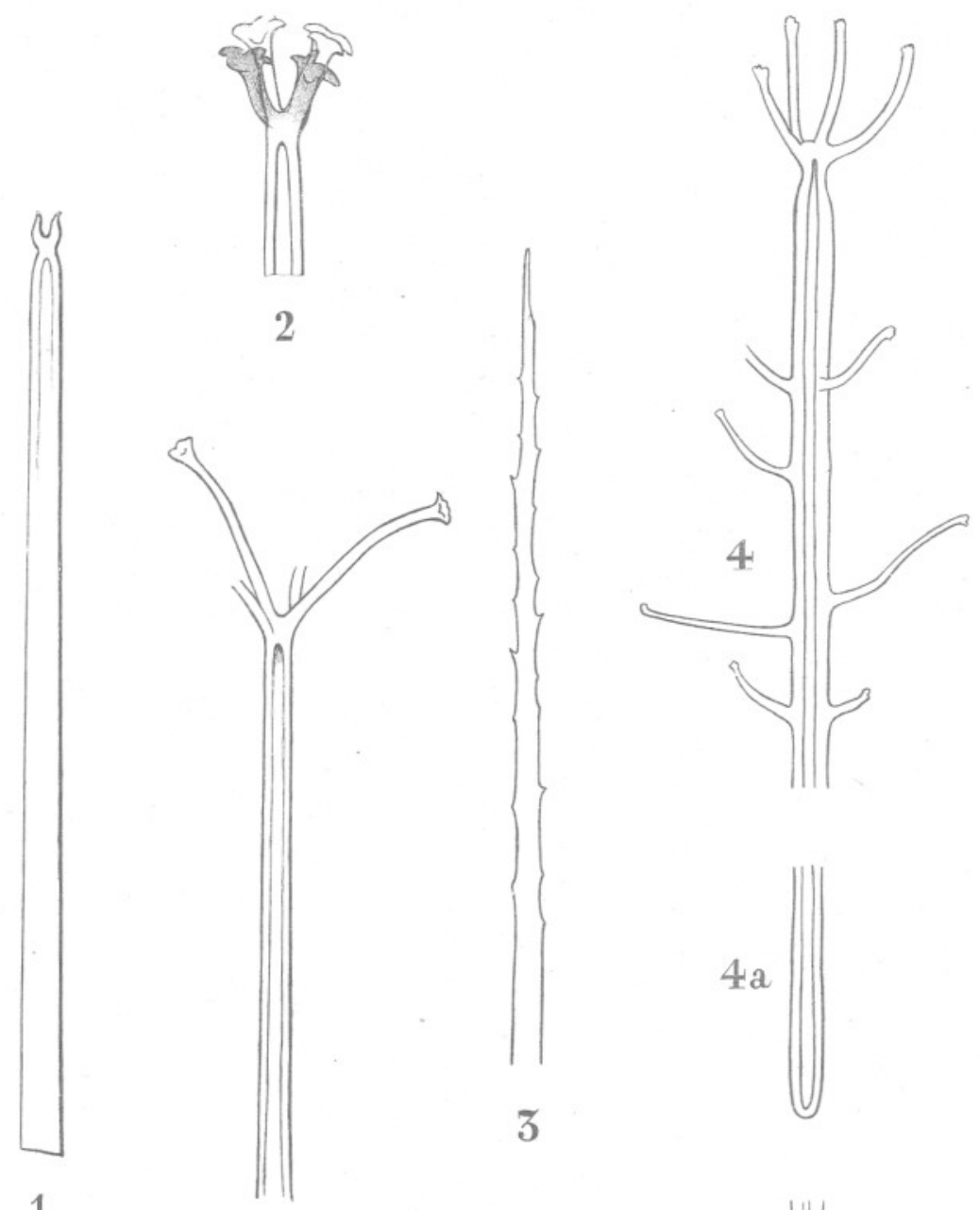

1

$2 a$
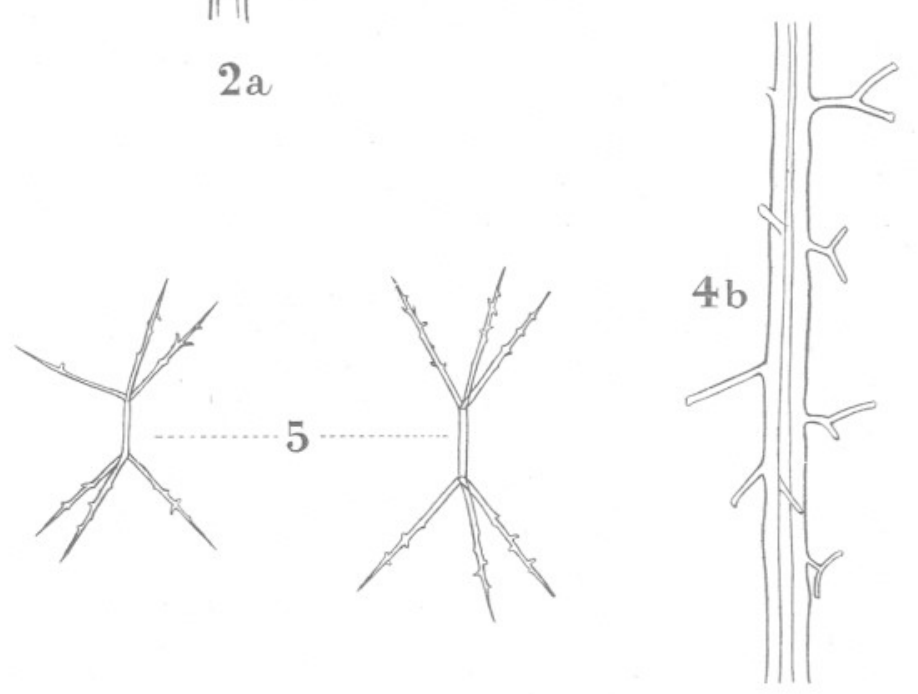

Drawn by Marion Lees

Bale \& Danielsson Ltd. lith. 


\section{Plate II}
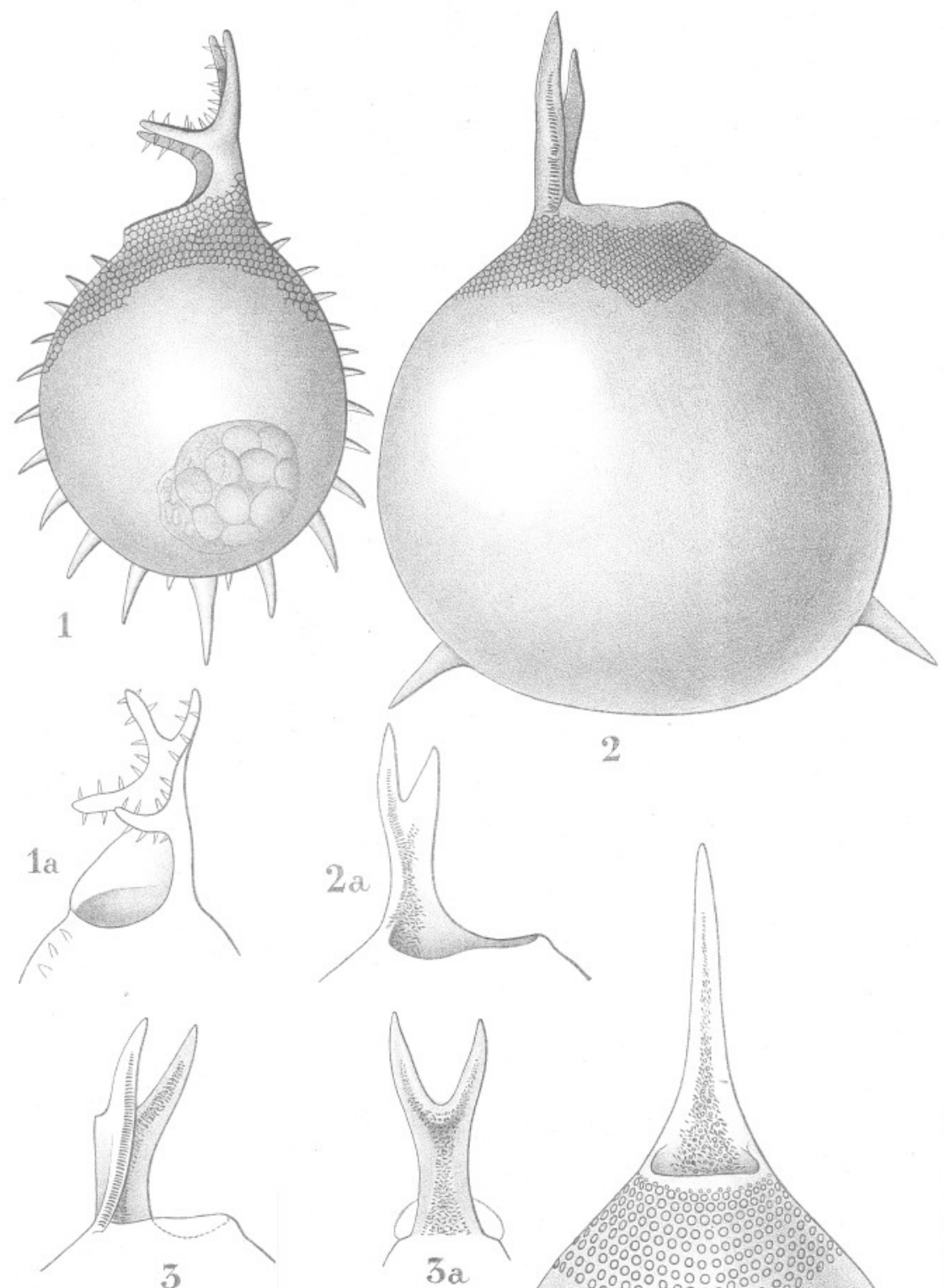

2

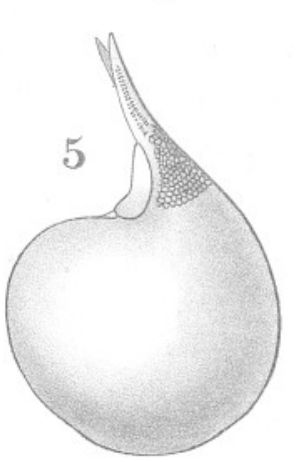

Drawn by Marion Lees. $5 a$

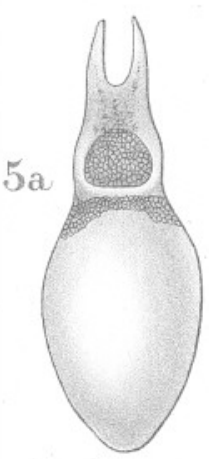

$3 a$
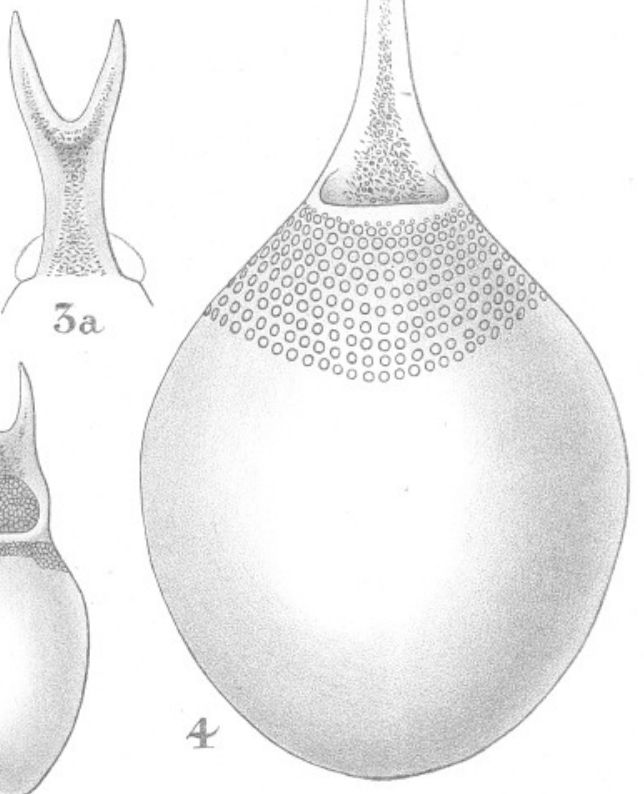

Bale \&Danielsson Ltd. lith 


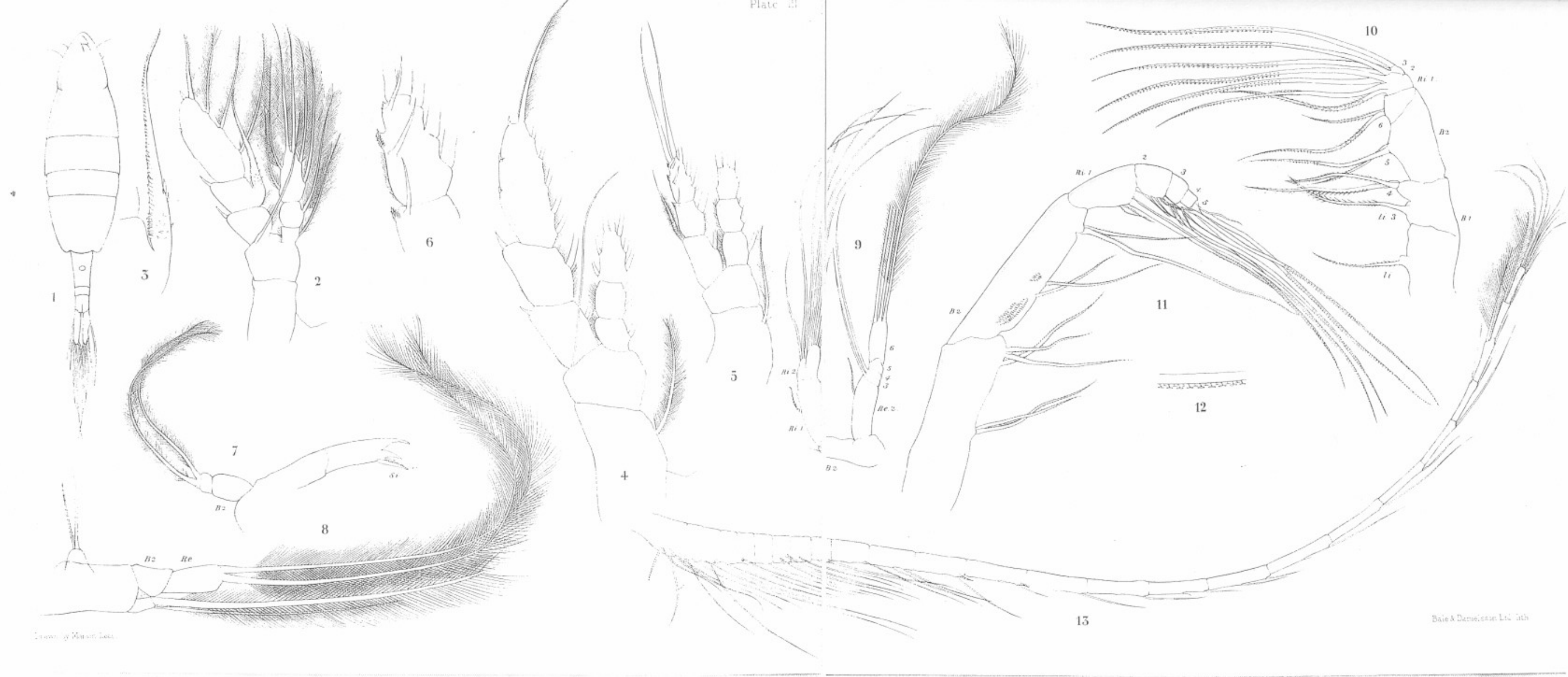




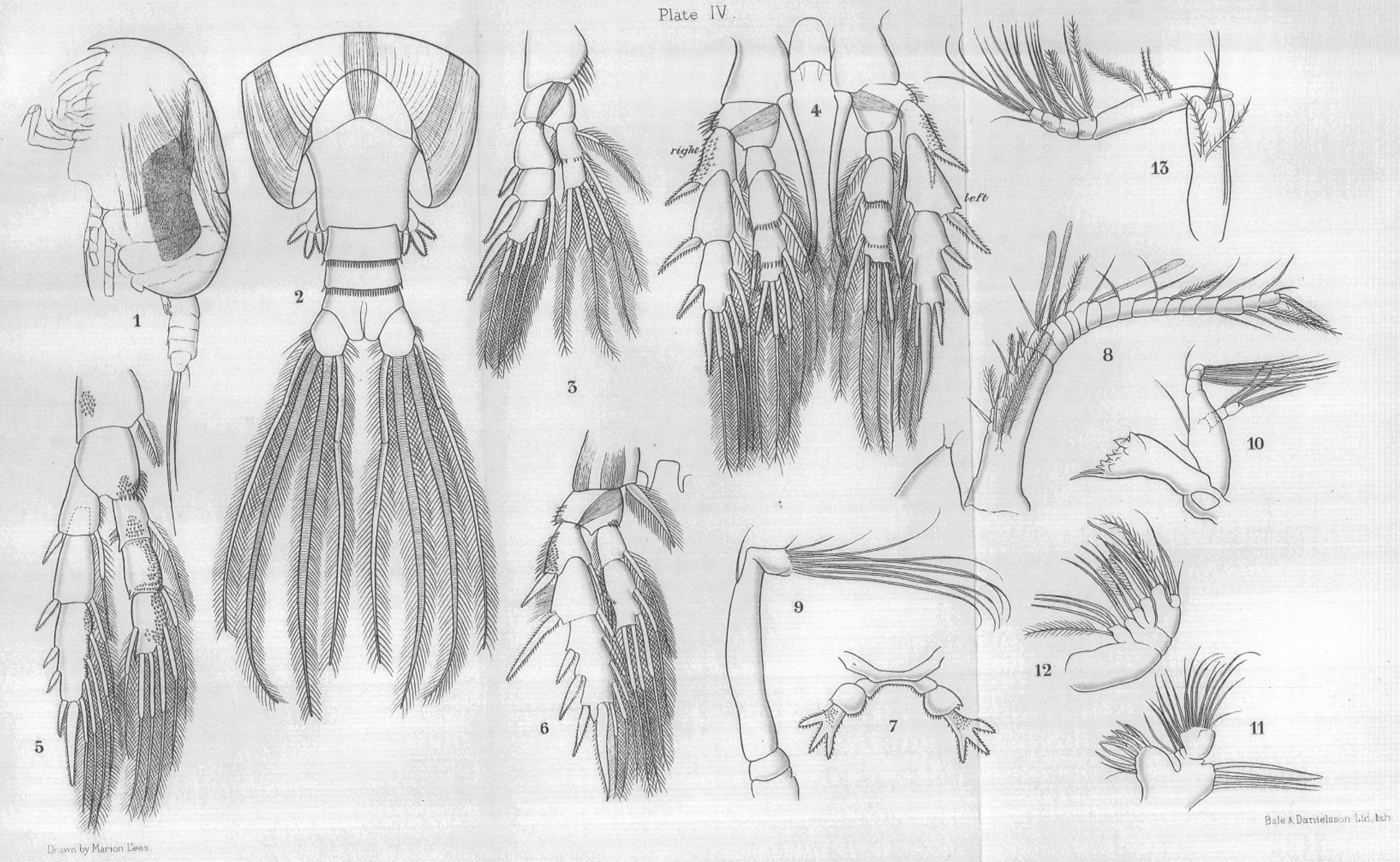

